\title{
Using Work Integrated Learning programmes as a strategy to broaden academic and workplace competencies
}

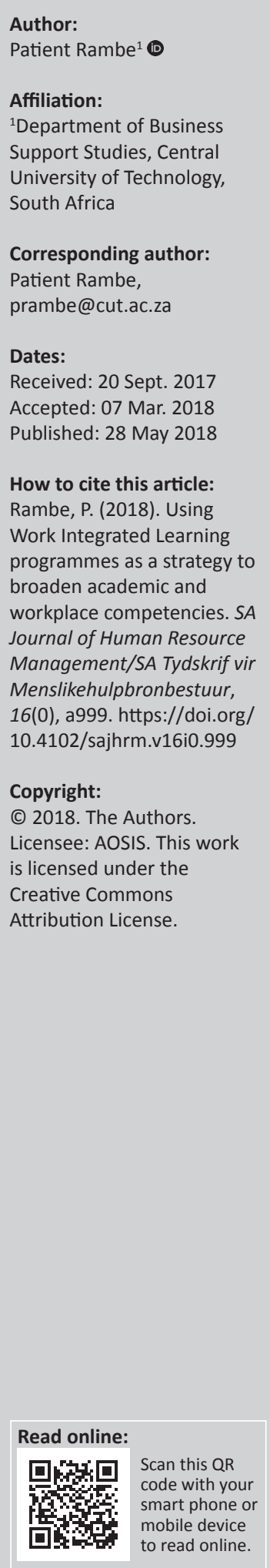

Orientation: Work Integrated Learning (WIL) is often hailed for leveraging students' swift and flexible adaptation to organisational work demands and accentuating the relevance of knowledge acquired in academic environments to work contexts. However, an inclusive view of WIL's impact on students' academic life, especially the broadening of their academic competences, is often occluded by a selective approach to WIL, which emphasises employers' professional expectations and ignores the nature and process of competence development of students.

Research purpose: To bridge the research gap created by employer-centred approaches, this study explores particular South African University of Technology (UoT) 'students' perceptions' on the influence of WIL programmes on the broadening of Office Management and Technology (OMT) competencies (i.e. knowledge, skills and abilities).

Motivation for the study: To promote an alternative approach to unravelling OMT competencies, which takes cognisance of the perceptions of students, who are the actual participants in WIL.

Research design, approach and method: The study drew on a quantitative case study of 94 OMT students from the UoT's two campuses who had been successfully placed at 20 organisations in South Africa.

Main findings: The findings demonstrated that students' participation in WIL enhanced their practical knowledge of space management, encouraged swift learning of work-based skills and abilities as well as facilitated the transfer of these competencies across a wide range of contexts, activities and tasks.

Practical and managerial implications: The strong correlation between course organisation and WIL's enhancement of space management knowledge, skills and abilities implies that educators and employers need to place more emphasis not just on their delivery methods but also on the selection and organisation of content, which is critical to such delivery.

Recommendations: The study recommended the strengthening of the entire WIL conceptualisation and implementation process (i.e. content selection, content organisation, teaching modalities and computer-assisted delivery) and its delivery regime to ensure sustained improvement of student competencies.

\section{Introduction}

The South African government and higher educational institutions regard the high youth employment rate and bleak job prospects in the country as reasons for extreme concern. National employment statistics reveal that about $48 \%$ of South Africans aged between 15 and 34 years were unemployed in the third-quarter of 2016 (Graham \& De Lannoy, 2016). The Statistics South Africa (Stats SA, n.d.) Quarterly labour force survey (QLFS) highlights a national unemployment rate of $27.7 \%$ between January and March 2017, which is a 1.2 percentage points increase from the fourth-quarter of 2016. As the year progressed, the youth unemployment rate escalated by 1.6 percentage points to $38.6 \%$, with $58.0 \%$ of unemployed people between aged between 15 and 34 years (Menon, 2017), thus further widening the gap of reaching the National Development Plan (NDP) target of 24 million employed people by 2030 (Lehohla, 2017). The 2017 QLFS further elaborates that men from previously marginalised groups, comprising black and mixed race, remain employed in semi-skilled and 
low-skilled occupations. These disconcerting statistics raise critical questions about the role of the university curriculum in sufficiently preparing students for gainful employment.

The aforementioned soaring youth unemployment rate raises interest as to how university curricula interventions, such as Work Integrated Learning (WIL), could be harnessed as a strategy for increasing student employability, through improving their academic and career management capabilities. Work Integrated Learning describes 'the practice of combining traditional academic study or formal learning, with student exposure to the world-of-work in their chosen profession' (Jackson, 2015, p. 350). This academic practice is often hailed for fostering employability skills critical to student entry into the workforce (Jackson, 2015); leveraging career management competencies (Jackson \& Wilton, 2016; Puncreobutr, Malee, \& Somjate, 2016); improving student-teacher relationships, which improve student performance (Salm, Johner, \& Luhanga, 2016); and improving self-reliance in complex work contexts (Organ, 2017).

\section{Problem statement}

Studies on the impact of WIL on broadening student work-related competences highlight some improvements in graduate employability and development of skills (Wilton, 2012), as well as the acquisition of professional competencies of practicum students (Salm et al., 2016). These studies either emphasise the employers' professional needs in relation to the development of workplace competencies or fail to tackle the nature and process of development of academic competencies of students. As such, the evaluation of the influence of WIL programmes on enhancing skills development remains predominantly outcomes-focused, with an employability bias and often ignores the mechanical processes in terms of the what, how and from whom students acquire these essential skills (Atkinson, 2016; Jackson, 2015). In other studies, the focus of attention often gravitates towards the enhancement of acquired competencies and the overall student experience (Simpson, Thyer, Van Nugteren, Mitchell, \& Werner, 2016), rather than on specific processes such as knowledge development and skill enhancement leading to the acquisition of particular competencies (Puncreobutr et al., 2016). Beckett (2004) and Jackson (2015) contend that competencies and generic skills are shaped as much by sensitivity to the 'processes' of learning, as they are by concerns over the outcomes of learning. Smith and Worsfold (2014) highlight that the success of WIL programmes is contingent on a variety of accidental or contextual, as well as deliberately designed, curriculum factors and hence the importance of measuring both the 'outcomes' of these programmes and the 'processes' by which these outcomes are generated. Consistent with the need to capture the process of competence development, this study explores a South African University of Technology (UoT) 'students' perceptions' on the effect particular of WIL programmes on the broadening of their Office Management and Technology (OMT) competencies.

\section{Literature review Work Integrated Learning and its variants}

From a university perspective, WIL describes (Atkinson, 2016):

learning that comprises a range of programmes and activities in which the theory of the learning is intentionally integrated with the practice of work through specifically designed curriculum, pedagogic practices and student engagement. (p. 2)

This means that WIL allows for the practical application of knowledge, concepts and skills in a simulated or actual work environment, as much as for the transfer of practical experience acquired from authentic work contexts into a university learning context to improve student performance. Although WIL often manifests in diverse formats and covers varying durations, intensity and foci areas, the commonly articulated formats include 'pre-course experience, sandwich course, cooperative education, cognitive apprenticeship or job shadowing, joint industry-university course, new traineeship or apprenticeship, placement or practicum, fieldwork, post-course internship' (Puncreobutr et al., 2016, p. 121). Although work-based practices such as job shadowing, career fairs and work-study are credited with providing students with exposure to workplace and career-oriented experiences, they are often not directly integrated into students' programmes of study and, as such, unfold as co- or extra-curricular engagements (McRae \& Johnston, 2016; Sattler, Wiggers, \& Arnold, 2011). It is beyond the scope of this article to unravel the individual traits of each WIL format because of its exclusive focus on work placements. Suffice to acknowledge that the location of each WIL format in the formal programme, its organisation, extent of formality, level of integration, duration and intensity of competence development vary considerably.

\section{Work Integrated Learning and competence development}

The growing body of literature on the benefits of WIL on competence development tends to intersect in the following areas: improving academic performance (Crawford \& Wang, 2015; Milne \& Caldicott, 2016), improving academic knowledge (Dressler \& Keeling, 2011), expanding the workbased knowledge of students (Maher, Pelly, Swanepoel, Sutakowsky, \& Hughes, 2015; Peters, Sattler, \& Kelland, 2014) and increasing the employability of graduates through broadening their professional skills (Biasini, Bohm, \& Rabadán-Gómez, 2016; Brimble \& Freudenberg, 2010; Tai, Molloy, Haines, \& Canny, 2016). Other studies have placed their emphasis on developing a professional identity and language of students (Burgess, Roberts, Blackr, \& Mellis, 2013), increasing the career management competencies of students and increasing local and regional collaborative engagement between the university, employers and industry (Atkinson, 2016; Henderson \& Trede, 2017; Khuong, 2016). With regard to the WIL-academic performance relationship, Crawford and Wang (2015) highlighted that Chinese students who undertook placements in their third year of study were seven times more likely to achieve good grades than those 
who opted out of work placements. The authors further reported that students with good grades in their first and second years of study were more likely to undertake placements than those with poor grades.

Much of the aforementioned research seems to lay emphasis on strengthening the learning outcomes of students, for example, targeting particular authentic competencies and improving the quality of industrial experience and exposure (Smith \& Worsfold, 2014), rather than focussing on the nature of programmes, including the selection of appropriate content, and the processes, such as course organisation and teaching modalities, which trigger and culminate in the acquisition of such competencies. As such, this outcomes-focused approach may be regarded as propagating a pre-occupation with the final 'product', rather than focussing on the processes involved in 'developing the product'. This may lead to educators who are not sufficiently preparing students for the world of work and nurturing students who harbour unrealistic expectations of an industry where operational competence is prioritised over academic competences (Barrows \& Johan, 2008; Khuong, 2016).

\section{Work Integrated Learning content selection and organisation}

The selection and organisation of relevant learning content to prepare students sufficiently for work place demands is fundamental to student success in WIL for two important reasons: (1) the reality that, while universities take charge of the management of the work-based programme, the learning environment is distant to the university campus; and (2) processes that enable student participation and attainment of learning outcomes occur within the 'workplace' or 'industry' (Henderson \& Trede, 2017). As the success of the evaluation of WIL lies at the intersection of the industry and the university (Henderson \& Trede, 2017; Henderson et al., 2010), the university should play a critical role in both the formative processes of content development (in preparation for WIL) and course organisation to ensure that they are sufficiently and seamlessly integrated into the WIL programme. This means that WIL learning experiences should deliberately integrate knowledge and understandings previously encountered by the student through various teaching and learning modalities with practices encountered in the workplace setting (Yorke, 2011). Therefore, sufficient preparation of knowledge, skills and understanding of learning outcomes prior to work-based learning; the rendering of support from academics and workplace supervisors; and the provision of facilitative conditions of the real-world context are all integral to meaningful student learning (Henderson \& Trede, 2017). Although the provision of relevant learning content and its appropriate organisation is fundamental to preparing the climate for knowledge transfer across diverse contexts, the responsibility of students is to reflect and document their experiences and apply them across different work-related contexts.

\section{Work Integrated Learning and teaching modalities}

Billet (2011) and Jackson (2015) emphasise the development of curricula and pedagogical practices that focus on the integration of workplace practice with classroom learning to ensure sufficient transfer of workplace skills to learning concepts acquired through direct instruction. The emphasis of such transfer is on appraising certain concepts, reinforcement of specific workplace behaviours and how these behaviours could inform critical problem-solving within work contexts. Although Billet's theorisation of knowledge integration emphasises pre-placement preparation, provision of support to allow for critical reflection in practice and seamless integration of these processes, there is no guarantee that provision of such support always translates into meaningful transfer of workplace technical skills.

Another instructional model that constitutes a variant of WIL is the sandwich programme, offered in the United Kingdom. The sandwich degrees constitute 4-year study programmes with a year-long industry or work placement sandwiched between the second and final years of the degree study period (Crawford \& Wang, 2015; Little \& Harvey, 2006). This model is founded on the assumption that industrial attachment and exposure increases experiential learning (Kolb, 1984; Jackson, 2015) through the practical application of concepts visualised and learned in university classrooms. Although experiential learning offered through clinical practicums and industrial placements is integral to 'procedural' learning, the model does not provide clear mechanisms for integrating and transferring concepts learned in classrooms into workplace contexts. That said, there is evidence to support the view that international students who undertake placements based on the sandwich model tend to improve their academic performance in their final year (Jones, Green, \& Higson, 2017).

A further approach to integrating practice with theory is that of simulations, which are pedagogical practices credited with increasing student articulation and executing workrelated tasks in classroom environments. They are considered effective and beneficial to students when they render 'realistic' experiences of the workplace or the commercial environment (Atkinson, 2016). These experiences can take the form of simulating 'real' business entities for business students, operationalisation of greenhouse environment for horticulture students and holding legal debates in a simulated court of law for law students.

\section{Methodology}

The sample comprised 94 OMT third year students from a UoT in South Africa who had successfully participated in, and completed, their WIL programme. The choice of OMT students was based on the impending reality of discontinuing the OMT Bachelor of Technology (BTech) course at this university in 2018 and replacing it with an advanced diploma, because of a shrinking job market for secretaries and administrators and student demands for greater value for money in the recession ridden South African economy. 
Brookfield (2012, p. 45) highlights that employers often prefer employing individuals with sophisticated office management experience and skills for the good reputation of their organisations and to increase organisational profit. The need to discontinue and re-brand the OMT course also arose from the rapid expansion of OMT competencies in the Information Age to include managing of computer documents, basic programming and computer-based communication such as Skype (Voice Over Internet Protocol). These competences are reported to require substantial levels of 'analysis and reasoning, [...] research, problem solving, and oral communication skills' (Van Zyn, 2005, p. 162) critical to preparing students adequately for the complex work environment.

\section{Procedures}

A survey approach was employed to collect data on students' perspectives on the influence of WIL programmes on broadening their OMT competencies. The WIL lecturers and coordinators provided the list and email addresses of students who had been successfully placed at particular organisations and participated in WIL $(N=94)$.

\section{Measures}

Section A: This section covered generic demographic data of the students, such as their gender, age, educational background and year of experience on attachment.

Sections $B$ and $C$ : In addressing students' perceptions, the researcher relied on retrieving as much information as possible from the questionnaires distributed to students. These sections' questions focused on the influence of content and participation in WIL programmes on the broadening of their competencies and the role of students in the assessment process.

\section{Reliability and validity of the instruments}

For adequate reliability, a construct's items must have Cronbach's alpha values of at least 0.700 . Any value less than 0.700 is indicative of a low internal consistency or reliability. The American Public Human Service Association (2012, p. 45) articulates that reliability pertains to the consistency of scores obtained for a particular item. The less the consistency within a given measurement, the less useful the data may be for purposes of analysis. Table 1 shows that all items in the questionnaire had high internal consistency as indicated by Cronbach's alpha values greater than 0.7. Overall, the whole questionnaire had a very high Cronbach's alpha value, thus making it highly reliable. Pretorius (2012) states that there are different reports about the acceptable values of alpha, ranging from 0.70 to 0.95 .

Factor analysis was conducted to determine the validity of each item measuring the constructs, namely knowledge of time management, knowledge of space management, skills learning and abilities enhancement. The results in Table 3 to Table 6 indicate that the latent factor (principal component) coefficients for the items measuring each construct were predominantly above 6. Bagozzi (2011) states that even though factor loadings greater than 0.7 are preferred, factor loadings less than 0.7 but above 0.6 are still acceptable. This means that many of the items were valid and sufficiently measured the constructs in question.

\section{Results}

\section{Students' biographical summary}

This section analyses the general biographical profile of the students who responded to this study.

\section{Demographic composition of the participants}

The results in Table 2 illustrate that the gender composition of respondents was 51\% $(n=48)$ males and $49 \%(n=46)$ females. The students were self-selected on the grounds that both genders were expected to participate in WIL in accordance with the requirements of the curriculum.

TABLE 2: Biographical information for students.

\begin{tabular}{llll}
\hline Biographical variable & Category & Frequency & Percentage \\
\hline Q1. Gender & Female & 46 & 49 \\
& Male & 48 & 51 \\
Q2. Age group & $<25$ years & 90 & 96 \\
& $25-34$ & 4 & 4 \\
Q3. Home language & English & 18 & 19 \\
& Afrikaans & 20 & 21 \\
& Sesotho & 30 & 32 \\
& IsiZulu & 10 & 11 \\
& IsiXhosa & 16 & 17 \\
Q4. Qualification & Matric and below & 84 & 89 \\
& FET or equivalent & 8 & 9 \\
& University degree or diploma & 2 & 2 \\
\hline \multirow{2}{*}{ Q9. Highest qualification } & Matric and below & 39 & 41 \\
& Tertiary certificate & 51 & 54 \\
& Diploma or degree & 4 & 4 \\
\hline
\end{tabular}

Q, question.

\begin{tabular}{|c|c|c|c|c|}
\hline Section & $N$ & $\begin{array}{l}\text { Number of } \\
\text { questionnaire items }\end{array}$ & Cronbach's alpha & Comment \\
\hline Overall influence of WIL on the enhancement of knowledge (questions 10-16) & 94 & 7 & 0.875 & High internal consistency \\
\hline Space management knowledge (questions 17-25) & 94 & 9 & 0.918 & High internal consistency \\
\hline Skills (questions 26-36) & 94 & 11 & 0.923 & High internal consistency \\
\hline Abilities (questions 28, 29, 30, 31, 32, 33) & 94 & 6 & 0.846 & High internal consistency \\
\hline All Likert scale questions & 94 & 33 & 0.967 & High internal consistency \\
\hline
\end{tabular}

WIL, Work Integrated Learning. 
Most students who participated in this study were mainly below the age of $25(96 \%)$. Only $4 \%$ of the students were in the age group of 25-34 years. The dominance of those below 25 years of age is indicative of the fact that most students who enrol for undergraduate university studies would typically be younger, as opposed to more mature adults.

A sizeable percentage (32\%) of respondents were Sesotho speaking followed by those Afrikaans (22\%), English (19\%), IsiXhosa (17\%) and IsiZulu speaking (11\%). In spite of the linguistic diversity reflected in the results, it is apparent that a majority of respondents were Sesotho and Afrikaans speaking. This demographic can be attributed to the site of investigation, where the majority of students enrolled are Sesotho, Afrikaans and English language speakers (Ferreira, 2011).

In terms of education, a majority (89\%) of respondents possessed a Matric qualification and below as their highest qualification. Nine per cent $(9 \%)$ of the respondents indicated that they possessed further education and training (FET) or equivalent qualifications, with only $2 \%$ possessing university degrees or diplomas.

\section{Knowledge of time management}

The study examined the overall influence of WIL on the enhancement of the competencies of OMT students who had been attached to organisations through WIL. As students had overwhelmingly positive responses to most items on the questionnaire, only those responses with the highest percentages and mean scores are reported in this study. As competencies comprise individuals' knowledge, skills and abilities, OMT student responses to questions that dealt with the influence of WIL on the enhancement of knowledge of time management are summarised in Table 3.
The Cronbach's alpha value of 0.875 indicates that the items that make up the construct of the overall influence of WIL on the enhancement of knowledge of time management have a high internal consistency. Hence, they can be summarised by a single measure and still represent all the items of this construct reliably.

All respondents strongly agreed that participation in WIL had a positive impact on their knowledge of planning of current and future task or work activities. The result demonstrates that $98.9 \%$ of the respondents strongly agreed that participation in WIL impacted positively on their knowledge of general time consciousness. Similarly, 97.9\% of them claimed that participation in WIL positively impacted on their knowledge of appropriate allocation of time to tasks. These finding demonstrate that students' time consciousness is enhanced through WIL placement practices such as the requirement for these individual attaches to keep a time log to determine how they expended their time productively and observe punctuality at work.

Of the respondents, $97.9 \%$ indicated that their participation in WIL assisted them in managing multiple conflicting priorities and in managing their time, which are key considerations in leveraging organisational productivity. This somewhat contradicts literature which suggests that multitasking causes serious productivity decline - loss of productivity as high as $40.0 \%$ when compared to single-tasking (Rubinstein, Meyer, \& Evans, 2001).

The measures of central tendency provided in Table 3 demonstrate high means score and low standard deviations, showing evidence of consistency of responses. Most of the mean scores on the impact of WIL on knowledge of time management were high: time consciousness (mean, $M=4.83, \mathrm{SD}=0.41)$, appropriate allocation of time to tasks $(M=4.79, \mathrm{SD}=0.46)$ and general time management $(M=4.78 ; \mathrm{SD}=0.47)$.

TABLE 3: Enhancement of knowledge of time management.

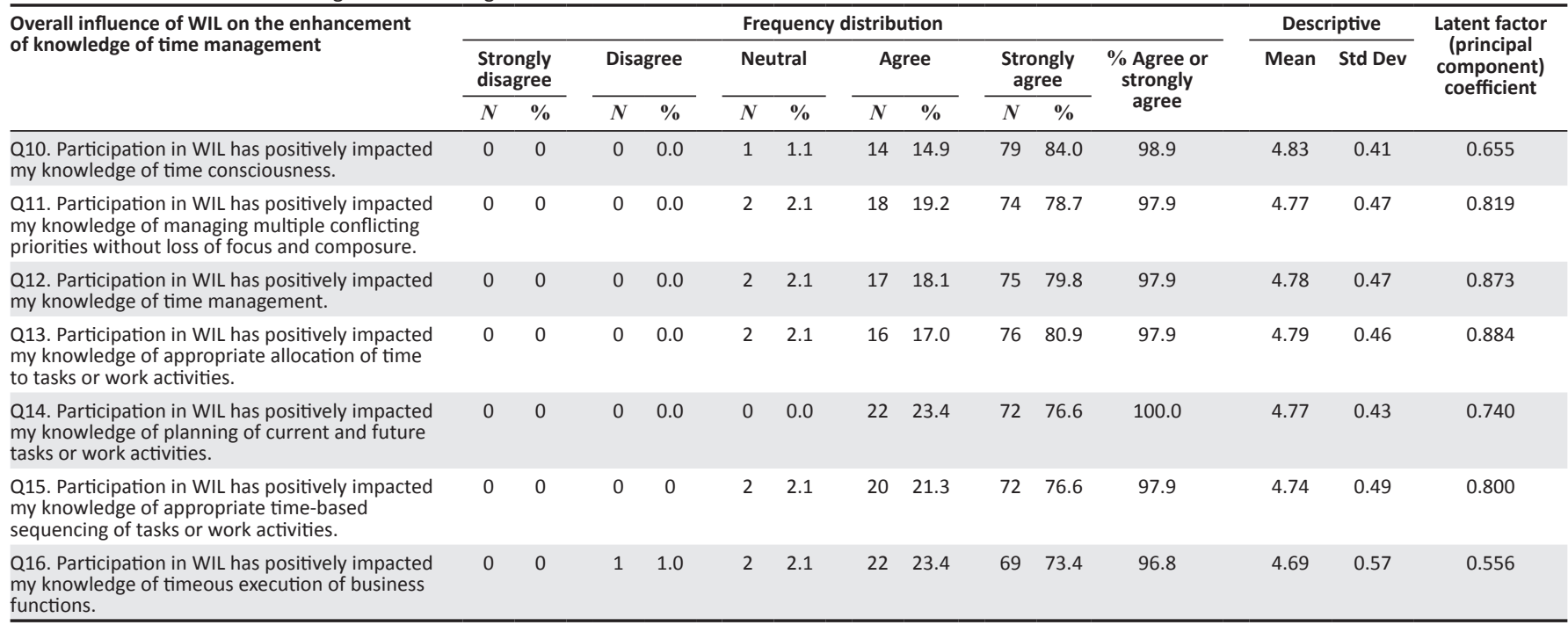

Cronbach's alpha $=0.875 ; \%$ of total variation accounted for by latent factor $=59.12$

WIL, work integrated learning; $Q$, question. 


\section{Space management knowledge}

Table 4 illustrates the results of the students' responses on WIL's effect on their knowledge of space management.

The Cronbach's alpha value of 0.918 indicates that the items that constitute the construct of space management knowledge have a high internal consistency. Hence, they can be summarised by a single measure and still represent all the items of this construct reliably.

A majority (98.9\%) of students indicated that WIL enhanced their knowledge of how to handle appropriately all paperwork in the office. This dominant percentage could mean that WIL opportunities improve the employment readiness of these future office managers, office administrators and secretaries.

Participation in WIL was conceived to impact on student management of office resources such as office space and technology. About $97.9 \%$ and $95.7 \%$ of students were of the opinion that participation in WIL positively impacted on their knowledge of adapting to new technology and managing tasks. The results indicate that $96.8 \%$ of the respondents were of the opinion that WIL had positively impacted their knowledge of managing space and creating an organised OMT office.

The high mean scores and low standard deviations in Table 4 show evidence of consistency of responses. Most mean scores on the impact of WIL on knowledge of space management were high: control over physical environment $(M=4.84$, $\mathrm{SD}=0.42)$, organisational functions and procedures of the office $(M=4.83, \mathrm{SD}=0.43)$ and appropriate handling of paperwork $(M=4.80, \mathrm{SD}=0.43)$.

\section{Skills learning}

Table 5 illustrates a summary of the results on the learning skills ingrained in the WIL programme.

The Cronbach's alpha value of 0.923 indicates that the items that constitute the construct of skills have a high internal consistency. Hence, they can be summarised by a single measure and still measure the skills factor (construct) reliably.

All $(100 \%)$ students concurred that participation in WIL improved their presentation skills, especially their articulation using relevant content owing to good oral presentation skills learnt in the workplace. All respondents $(100 \%)$ strongly agreed that participation in WIL enhanced their oral skills such as speaking with confidence and using clear and concise sentences.

A total of $97.9 \%$ of the students strongly agreed that participation in WIL impacted positively on their computer and technical skills. This highlights that students' computer skills, such as word processing, PowerPoint presentations, emailing and technical drawing, improved through participation in WIL.

Table 5 also shows consistency of responses judging from the high means and small deviations from the means. Most mean scores on the impact of WIL on skills learning were high: communication skills $(M=4.87, \mathrm{SD}=0.39)$, writing skills $(M=4.83, \mathrm{SD}=0.43)$ and oral skills $(M=4.83, \mathrm{SD}=0.38)$.

\section{Abilities enhancement}

The summary statistics on the effect of WIL on the enhancement of abilities are presented in Table 6. The table indicates that, in general, the students' participation in WIL affected their abilities positively.

TABLE 4: Space management knowledge.

\begin{tabular}{|c|c|c|c|c|c|c|c|c|c|c|c|c|c|c|}
\hline \multirow[t]{3}{*}{ Space management knowledge } & \multicolumn{11}{|c|}{ Frequency distribution } & \multicolumn{2}{|c|}{ Descriptive } & \multirow{3}{*}{$\begin{array}{l}\text { Latent factor } \\
\text { (principal } \\
\text { component) } \\
\text { coefficient }\end{array}$} \\
\hline & \multicolumn{2}{|c|}{$\begin{array}{l}\text { Strongly } \\
\text { disagree }\end{array}$} & \multicolumn{2}{|c|}{ Disagree } & \multicolumn{2}{|c|}{ Neutral } & \multicolumn{2}{|c|}{ Agree } & \multicolumn{2}{|c|}{$\begin{array}{c}\text { Strongly } \\
\text { agree }\end{array}$} & \multirow{2}{*}{$\begin{array}{l}\% \text { Agree or } \\
\text { strongly } \\
\text { agree }\end{array}$} & \multirow[t]{2}{*}{ Mean } & \multirow[t]{2}{*}{ Std. Dev. } & \\
\hline & $N$ & $\%$ & $N$ & $\%$ & $N$ & $\%$ & $N$ & $\%$ & $N$ & $\%$ & & & & \\
\hline $\begin{array}{l}\text { Q17. Participation in WIL has positively } \\
\text { impacted my knowledge of managing space } \\
\text { such as keeping a clean and organised OMT } \\
\text { office. }\end{array}$ & 0 & 0 & 0 & 0 & 3 & 3.2 & 17 & 18.1 & 74 & 78.7 & 96.8 & 4.76 & 0.50 & 0.766 \\
\hline $\begin{array}{l}\text { Q18. Participation in WIL has positively } \\
\text { impacted my demonstration of advanced } \\
\text { proficiency by quickly adapting to new } \\
\text { technology and easily acquiring new technical } \\
\text { skills. }\end{array}$ & 0 & 0 & 0 & 0 & 3 & 3.2 & 17 & 18.1 & 74 & 78.7 & 96.8 & 4.76 & 0.50 & 0.596 \\
\hline $\begin{array}{l}\text { Q19. Participation in WIL has positively } \\
\text { impacted my appropriate handling of all } \\
\text { paperwork. }\end{array}$ & 0 & 0 & 0 & 0 & 1 & 1.1 & 17 & 18.1 & 76 & 80.9 & 98.9 & 4.80 & 0.43 & 0.788 \\
\hline $\begin{array}{l}\text { Q20. Participation in WIL has positively } \\
\text { impacted my maintenance of control over the } \\
\text { physical environment. }\end{array}$ & 0 & 0 & 0 & 0 & 2 & 2.1 & 11 & 11.7 & 81 & 86.2 & 97.9 & 4.84 & 0.42 & 0.835 \\
\hline \multirow{3}{*}{$\begin{array}{l}\text { Q22. Participation in WIL has positively } \\
\text { impacted my knowledge of the organisational } \\
\text { functions and procedures of the office. }\end{array}$} & 0 & 0 & 0 & 0 & 2 & 2.1 & 12 & 12.8 & 80 & 85.1 & 97.9 & 4.83 & 0.43 & 0.927 \\
\hline & - & 0 & - & 0 & - & 3.2 & - & 9.6 & - & 87.2 & & & & \\
\hline & - & 0 & - & 0 & - & 2.1 & - & 28.7 & - & 69.2 & & & & \\
\hline
\end{tabular}

Cronbach's alpha $=0.918 ; \%$ of total variation accounted for by latent factor $=62.56$.

WIL, work integrated learning; OMT, office management and technology; $Q$, question. 


\begin{tabular}{|c|c|c|c|c|c|c|c|c|c|c|c|c|c|c|}
\hline \multirow[t]{3}{*}{ Skills } & \multicolumn{11}{|c|}{ Frequency distribution (\%) } & \multicolumn{2}{|c|}{ Descriptives } & \multirow{3}{*}{$\begin{array}{l}\text { Latent factor } \\
\text { (principal } \\
\text { component) } \\
\text { coefficient }\end{array}$} \\
\hline & \multicolumn{2}{|c|}{$\begin{array}{l}\text { Strongly } \\
\text { disagree }\end{array}$} & \multicolumn{2}{|c|}{ Disagree } & \multicolumn{2}{|c|}{ Neutral } & \multicolumn{2}{|c|}{ Agree } & \multicolumn{2}{|c|}{$\begin{array}{c}\text { Strongly } \\
\text { agree }\end{array}$} & \multirow{2}{*}{$\begin{array}{l}\text { \% Agree or } \\
\text { strongly } \\
\text { agree }\end{array}$} & \multirow[t]{2}{*}{ Mean } & \multirow[t]{2}{*}{ Std. Dev. } & \\
\hline & $N$ & $\%$ & $N$ & $\%$ & $N$ & $\%$ & $N$ & $\%$ & $N$ & $\%$ & & & & \\
\hline $\begin{array}{l}\text { Q26. Participation in WIL has positively impacted } \\
\text { on my computer and technical skills such as } \\
\text { displaying proficiency using standard office } \\
\text { equipment like a personal computer, } \\
\text { fax, photocopier and scanner. }\end{array}$ & 0 & 0 & 0 & 0 & 2 & 2.1 & 15 & 16.0 & 77 & 81.9 & 97.9 & 4.80 & 0.45 & 0.699 \\
\hline $\begin{array}{l}\text { Q28. Engagement in WIL has enhanced my } \\
\text { leadership skills such as: Team leadership. }\end{array}$ & 0 & 0 & 0 & 0 & 5 & 5.3 & 11 & 11.7 & 78 & 82.9 & 94.7 & 4.78 & 0.53 & 0.875 \\
\hline $\begin{array}{l}\text { Q29. Engagement in WIL has enhanced my } \\
\text { leadership skills such as co-supervision of } \\
\text { colleagues' activities. }\end{array}$ & 0 & 0 & 0 & 0 & 3 & 3.2 & 14 & 14.9 & 77 & 81.9 & 96.8 & 4.79 & 0.48 & 0.868 \\
\hline $\begin{array}{l}\text { Q31. Engagement in WIL has enhanced my } \\
\text { leadership skills such as petty cash management } \\
\text { skills (e.g. invoicing, receipting, computer based } \\
\text { filing, corporate banking). }\end{array}$ & 0 & 0 & 1 & 1.1 & 3 & 3.2 & 8 & 8.5 & 82 & 87.2 & 95.7 & 4.82 & 0.53 & 0.857 \\
\hline $\begin{array}{l}\text { Q32. Engagement in WIL has enhanced my } \\
\text { leadership skills such as listening skills, for } \\
\text { example, listen actively to OMT lecturers. }\end{array}$ & 0 & 0 & 1 & 1.1 & 1 & 1.1 & 32 & 34.0 & 60 & 63.8 & 97.9 & 4.61 & 0.57 & 0.627 \\
\hline $\begin{array}{l}\text { Q33. Engagement in WIL has enhanced my oral } \\
\text { skills to speak with confidence using clear and } \\
\text { concise sentences. }\end{array}$ & 0 & 0 & 0 & 0 & 0 & 0 & 16 & 17.0 & 78 & 83.0 & 100.0 & 4.83 & 0.38 & 0.543 \\
\hline $\begin{array}{l}\text { Q34. Engagement in WIL has enhanced my written } \\
\text { skills such as producing well thought-out texts. }\end{array}$ & 0 & 0 & 0 & 0 & 2 & 2.1 & 12 & 12.8 & 80 & 85.1 & 97.9 & 4.83 & 0.43 & 0.714 \\
\hline $\begin{array}{l}\text { Q35. Engagement in WIL has enhanced } \\
\text { my written skills such as professional } \\
\text { correspondence free from grammatical and } \\
\text { spelling errors. }\end{array}$ & 0 & 0 & 1 & 1.1 & 2 & 2.1 & 10 & 10.6 & 81 & 86.2 & 96.8 & 4.82 & 0.51 & 0.763 \\
\hline
\end{tabular}

Cronbach's alpha $=0.923 ; \%$ of total variation accounted for by latent factor $=59.39$.

WIL, work integrated learning; OMT, office management and technology; Q, question; Std. Dev., standard deviation.

TABLE 6: Abilities enhancement.

\begin{tabular}{|c|c|c|c|c|c|c|c|c|c|c|c|c|c|c|}
\hline \multirow[t]{3}{*}{ Abilities } & \multicolumn{11}{|c|}{ Frequency distribution (\%) } & \multicolumn{2}{|c|}{ Descriptives } & \multirow{3}{*}{$\begin{array}{l}\text { Latent factor } \\
\text { (principal } \\
\text { component) } \\
\text { coefficient }\end{array}$} \\
\hline & \multicolumn{2}{|c|}{$\begin{array}{l}\text { Strongly } \\
\text { disagree }\end{array}$} & \multicolumn{2}{|c|}{ Disagree } & \multicolumn{2}{|c|}{ Neutral } & \multicolumn{2}{|c|}{ Agree } & \multicolumn{2}{|c|}{$\begin{array}{l}\text { Strongly } \\
\text { agree }\end{array}$} & \multirow{2}{*}{$\begin{array}{l}\text { \% Agree or } \\
\text { strongly } \\
\text { agree }\end{array}$} & \multirow[t]{2}{*}{ Mean } & \multirow[t]{2}{*}{ Std. Dev. } & \\
\hline & $N$ & $\%$ & $N$ & $\%$ & $N$ & $\%$ & $N$ & $\%$ & $N$ & $\%$ & & & & \\
\hline $\begin{array}{l}\text { Q37. My participation in WIL has improved } \\
\text { my creative abilities. }\end{array}$ & 0 & 0 & 0 & 0 & 3 & 3.2 & 9 & 9.6 & 82 & 87.2 & 96.8 & 4.84 & 0.45 & 0.776 \\
\hline $\begin{array}{l}\text { Q38. My participation in WIL has improved } \\
\text { my ability to operate office machines. }\end{array}$ & 0 & 0 & 0 & 0 & 3 & 3.2 & 7 & 7.5 & 84 & 89.4 & 96.8 & 4.86 & 0.43 & 0.883 \\
\hline $\begin{array}{l}\text { Q39. My participation in WIL has improved } \\
\text { my ability to follow guidelines or procedures for } \\
\text { the preparation of administrative forms. }\end{array}$ & 0 & 0 & 0 & 0 & 2 & 2.1 & 7 & 7.5 & 85 & 90.4 & 97.9 & 4.88 & 0.38 & 0.893 \\
\hline $\begin{array}{l}\text { Q40. My participation in WIL has improved my } \\
\text { ability to maintain a good working relationship } \\
\text { with a diverse workforce, customers and visitors. }\end{array}$ & 0 & 0 & 0 & 0 & 2 & 2.1 & 5 & 5.3 & 87 & 92.6 & 97.9 & 4.90 & 0.36 & 0.904 \\
\hline $\begin{array}{l}\text { Q41. My participation in WIL has improved } \\
\text { my ability to lead and provide instruction to } \\
\text { clerical support staff. }\end{array}$ & 0 & 0 & 0 & 0 & 1 & 1.1 & 31 & 33.0 & 62 & 67.0 & 98.9 & 4.65 & 0.50 & 0.553 \\
\hline $\begin{array}{l}\text { Q42. My participation in WIL has improved } \\
\text { my ability to maintain confidentiality of } \\
\text { documents and office information. }\end{array}$ & 0 & 0 & 0 & 0 & 1 & 1.1 & 10 & 10.6 & 83 & 88.3 & 98.9 & 4.87 & 0.37 & 0.540 \\
\hline
\end{tabular}

Cronbach's alpha $=0.846 ; \%$ of total variation accounted for by latent factor $=59.91$

WIL, Work Integrated Learning; Q, question; Std. Dev., standard deviation.

The Cronbach's alpha value of 0.846 indicates that the items that constitute the construct of abilities have a high internal consistency. Hence, they can be summarised by a single measure and still measure the abilities factor (construct) reliably.
There was a strong affirmation (98.9\%) among students of the potential of WIL to improve their capacity to provide leadership to clerical and support staff. A similar percentage (98.9\%) also reiterated the capacity of WIL to engender their confidence in the delivery of their duties. A demonstrable 
percentage (97.9\%) agreed to the capacity of WIL to improve their ability to follow procedures in the preparation of administration forms and managing their relationships with all other stakeholders.

Consistency of responses manifested in high means and low standard deviations. Most mean scores on the impact of WIL on abilities enablement were high: maintaining good working relationships $(M=4.90, \mathrm{SD}=0.36)$, following procedures for preparing forms $(M=4.88, \mathrm{SD}=0.38)$ and maintaining confidentiality of documents $(M=4.87, \mathrm{SD}=037)$.

As the study emphasises the role of WIL processes rather than concentrating on WIL outcomes, the study also factors in content selection, content organisation, teaching methodologies and curricula delivery into the WIL process.

\section{Content selection}

The questions on content selection related to the relevance and appropriateness of the academic content that the students learnt in their lectures. The content selection construct is presented first and its relationship with WIL is presented later in a cross tabulation that shows correlations between constructs.

The Cronbach's alpha value of 0.899 indicates that the items that constitute the construct of lecture content selection have a high internal consistency. Hence, they can be summarised by a single measure and still measure the construct reliably.

The high mean and low standard deviations in Table 7 also demonstrated the consistency of responses. Most responses on lecturers' choice of content had high mean scores: familiarising students with space management $(M=4.87, \mathrm{SD}=0.34)$, familiarising students with office management knowledge $(M=4.86, \mathrm{SD}=0.40)$ and familiarising students with time management $(M=4.85, \mathrm{SD}=0.39)$.

\section{Course organisation - Factor 1}

As the study highlighted the value of understanding WIL processes and not just its outcomes, it considered course organisation as a typical factor integral to developing such WIL processes. Therefore, student perceptions on the effects of course organisation on WIL were examined.

The Cronbach's alpha value of 0.940 indicates that the items that constitute the first sub-construct of course organisation have very high internal consistency. Hence, they can be summarised by a single measure and still represent all the 10 items of the construct reliably (Table 8).

The results of the Kaiser-Meyer-Olkin Measure of Sampling showed sampling adequacy $(0.877 ; \mathrm{df}=253$, sig. $=0.000)$, supported the conduct of factor analysis and that the questionnaire items can be split into sub-constructs as they were highly correlated. The factors were split into three sub

TABLE 7: Lecturers' content selection.

\begin{tabular}{|c|c|c|c|c|c|c|c|c|c|c|c|c|c|c|}
\hline \multirow[t]{3}{*}{ Lectures content selection } & \multicolumn{11}{|c|}{ Frequency distribution (\%) } & \multicolumn{2}{|c|}{ Descriptives } & \multirow{3}{*}{$\begin{array}{l}\text { Latent factor } \\
\text { (principal } \\
\text { component) } \\
\text { coefficient }\end{array}$} \\
\hline & \multicolumn{2}{|c|}{$\begin{array}{l}\text { Strongly } \\
\text { disagree }\end{array}$} & \multicolumn{2}{|c|}{ Disagree } & \multicolumn{2}{|c|}{ Neutral } & \multicolumn{2}{|c|}{ Agree } & \multicolumn{2}{|c|}{$\begin{array}{l}\text { Strongly } \\
\text { agree }\end{array}$} & \multirow{2}{*}{$\begin{array}{l}\text { \% Agree or } \\
\text { strongly } \\
\text { agree }\end{array}$} & \multirow[t]{2}{*}{ Mean } & \multirow[t]{2}{*}{ Std. Dev. } & \\
\hline & $N$ & $\%$ & $N$ & $\%$ & $N$ & $\%$ & $N$ & $\%$ & $N$ & $\%$ & & & & \\
\hline $\begin{array}{l}\text { Q43. The lecturers' choice of content taught } \\
\text { was helpful in familiarising me with adaptability } \\
\text { knowledge such as managing multiple } \\
\text { conflicting OMT priorities without loss of } \\
\text { composure. }\end{array}$ & 0 & 0 & 0 & 0 & 2 & 2.1 & 13 & 13.8 & 79 & 84.0 & 97.9 & 4.82 & 0.44 & 0.836 \\
\hline $\begin{array}{l}\text { Q45. The lecturers' choice of content taught } \\
\text { was helpful in familiarising me with space } \\
\text { management knowledge such as keeping a } \\
\text { clean and organised OMT office. }\end{array}$ & 0 & 0 & 0 & 0 & 1 & 1.1 & 12 & 12.8 & 81 & 86.2 & 98.9 & 4.85 & 0.39 & 0.817 \\
\hline $\begin{array}{l}\text { Q46. The lecturers' choice of content taught } \\
\text { was helpful in familiarising me with space } \\
\text { management knowledge such as appropriately } \\
\text { handling all OMT paperwork. }\end{array}$ & 0 & 0 & 0 & 0 & 0 & 0 & 12 & 12.8 & 82 & 87.2 & 100.0 & 4.87 & 0.34 & 0.832 \\
\hline $\begin{array}{l}\text { Q47. The lecturers' choice of content taught } \\
\text { was helpful in familiarising me with space } \\
\text { management knowledge such as maintaining } \\
\text { control over the physical OMT environment. }\end{array}$ & 0 & 0 & 0 & 0 & 0 & 0 & 28 & 29.8 & 66 & 70.2 & 100.0 & 4.70 & 0.46 & 0.6 \\
\hline $\begin{array}{l}\text { Q48. The lecturers' choice of content taught } \\
\text { was helpful in familiarising me with task } \\
\text { management knowledge such as balancing } \\
\text { conflicting OMT priorities in order to manage } \\
\text { workflow. }\end{array}$ & 0 & 0 & 0 & 0 & 3 & 3.2 & 11 & 11.7 & 80 & 85.1 & 96.8 & 4.82 & 0.46 & 0.776 \\
\hline $\begin{array}{l}\text { Q49. The lecturers' choice of content taught } \\
\text { was helpful in familiarising me with office } \\
\text { management knowledge such as the appropriate } \\
\text { handling of all paperwork. }\end{array}$ & 0 & 0 & 0 & 0 & 2 & 2.1 & 9 & 9.6 & 83 & 88.3 & 97.9 & 4.86 & 0.40 & 0.841 \\
\hline
\end{tabular}

Cronbach's alpha $=0.899 ; \%$ of total variation accounted for by latent factor $=64.150$.

OMT, Office Management and Technology; Q, question; Std. Dev., standard deviation. 


\begin{tabular}{|c|c|c|c|c|c|c|c|c|c|c|c|c|c|c|}
\hline \multirow[t]{3}{*}{ Course organisation 1} & \multicolumn{11}{|c|}{ Frequency distribution (\%) } & \multicolumn{2}{|c|}{ Descriptives } & \multirow{3}{*}{$\begin{array}{l}\text { Latent factor } \\
\text { (principal } \\
\text { component) } \\
\text { coefficient }\end{array}$} \\
\hline & \multicolumn{2}{|c|}{$\begin{array}{l}\text { Strongly } \\
\text { disagree }\end{array}$} & \multicolumn{2}{|c|}{ Disagree } & \multicolumn{2}{|c|}{ Neutral } & \multicolumn{2}{|c|}{ Agree } & \multicolumn{2}{|c|}{$\begin{array}{c}\text { Strongly } \\
\text { agree }\end{array}$} & \multirow{2}{*}{$\begin{array}{l}\text { \% Agree or } \\
\text { strongly } \\
\text { agree }\end{array}$} & \multirow[t]{2}{*}{ Mean } & \multirow[t]{2}{*}{ Std Dev } & \\
\hline & $N$ & $\%$ & $N$ & $\%$ & $N$ & $\%$ & $N$ & $\%$ & $N$ & $\%$ & & & & \\
\hline $\begin{array}{l}\text { Q57. Content quality improved my written skills } \\
\text { such as: Producing well thought-out OMT ideas } \\
\text { in texts. }\end{array}$ & 0 & 0 & 0 & 0 & 1 & 1.1 & 13 & 13.3 & 80 & 85.1 & 98.9 & 4.84 & 0.40 & 0.773 \\
\hline $\begin{array}{l}\text { Q58. Content quality improved my written skills } \\
\text { such as professional correspondence on OMT } \\
\text { issues free from grammatical and spelling errors. }\end{array}$ & 0 & 0 & 0 & 0 & 1 & 1.1 & 14 & 14.9 & 79 & 84.0 & 98.9 & 4.83 & 0.41 & 0.765 \\
\hline $\begin{array}{l}\text { Q60. Quality of OMT content improved my OMT } \\
\text { computer and technical skills such as } \\
\text { demonstrating advanced proficiency by quickly } \\
\text { adapting to new technology and easily acquiring } \\
\text { new technical skills. }\end{array}$ & 0 & 0 & 0 & 0 & 2 & 2.1 & 10 & 10.6 & 82 & 87.2 & 97.9 & 4.85 & 0.41 & 0.840 \\
\hline $\begin{array}{l}\text { Q63. Content significance improved my OMT } \\
\text { leadership skills such as co-supervision of } \\
\text { colleagues' activities. }\end{array}$ & 0 & 0 & 0 & 0 & 1 & 1.1 & 20 & 21.3 & 73 & 77.7 & 98.9 & 4.77 & 0.45 & 0.759 \\
\hline $\begin{array}{l}\text { Q64. Content significance improved my OMT } \\
\text { leadership skills such as people management } \\
\text { skills (e.g. coordination of efforts from different } \\
\text { people). }\end{array}$ & 0 & 0 & 0 & 0 & 2 & 2.1 & 18 & 19.2 & 74 & 78.7 & 97.9 & 4.77 & 0.47 & 0.834 \\
\hline $\begin{array}{l}\text { Q65. Content significance improved my OMT } \\
\text { leadership skills such as petty cash management } \\
\text { skills (e.g. invoicing, receipting, computer based } \\
\text { filing and corporate banking). }\end{array}$ & 0 & 0 & 0 & 0 & 2 & 2.1 & 20 & 21.3 & 72 & 76.6 & 97.9 & 4.74 & 0.49 & 0.862 \\
\hline $\begin{array}{l}\text { Q66. Content significance improved my OMT } \\
\text { leadership skills such as listening skills, for } \\
\text { example, listening actively to OMT lecturers. }\end{array}$ & 0 & 0 & 0 & 0 & 1 & 1.1 & 16 & 17.0 & 77 & 81.9 & 98.9 & 4.81 & 0.42 & 0.871 \\
\hline $\begin{array}{l}\text { Q67. Understanding of the lesson plan of the } \\
\text { OMT course enhanced my ability to operate } \\
\text { office machines. }\end{array}$ & 0 & 0 & 0 & 0 & 0 & 0 & 10 & 10.6 & 84 & 89.4 & 100.0 & 4.89 & 0.31 & 0.747 \\
\hline $\begin{array}{l}\text { Q68. Understanding of the lesson plan of the } \\
\text { OMT course enhanced my creative thinking } \\
\text { abilities. }\end{array}$ & 0 & 0 & 0 & & 1 & 1.1 & 11 & 11.7 & 82 & 87.2 & 98.9 & 4.86 & 0.38 & 0.863 \\
\hline $\begin{array}{l}\text { Q69. Understanding of the lesson plan of the } \\
\text { OMT course enhanced my ability to follow } \\
\text { guidelines or procedures for the preparation } \\
\text { of administrative forms. }\end{array}$ & 0 & 0 & 0 & 0 & 1 & 1.1 & 7 & 7.5 & 86 & 91.5 & 98.9 & 4.90 & 0.33 & 0.778 \\
\hline
\end{tabular}

Cronbach's alpha $=0.940 ; \%$ of total variation accounted for by latent factor $=65.73$.

OMT, Office Management and Technology; Q, question; Std. Dev., standard deviation.

constructs. The result of exploratory factor analysis showed that the factors for most items ranged from 0.561 to 0.775 , thus ranged from acceptable to adequate.

The high means scores and low standard deviations demonstrated consistency of responses. Most responses on the effects of course organisation on WIL had high mean scores: ability to follow guidelines for preparing forms ( $M=4.90,0.33)$, enhancing ability to operate machines $(M=4.89, \mathrm{SD}=0.31)$ and enhancing critical thinking abilities $(M=4.86, \mathrm{SD}=038)$.

\section{Course organisation - Factor 2}

The results for the second sub-construct of course organisation are presented in Table 9.

A Cronbach's alpha value of 0.929 indicates that the items that constitute the second sub-construct of course organisation have a very high internal consistency. Hence, they can be summarised by a single measure.

Most mean scores on the effect of course organisation were high demonstrating consistency of responses. These means and standard deviations were as follows: knowledge of sequencing OMT tasks $(M=4.95, \mathrm{SD}=0.23)$, grasping
OMT practicals $(M=4.89, \mathrm{SD}=0.32)$ and listening skills $(M=4.89$, SD $=0.32)$.

\section{Course organisation sub-construct 3 - Factor 3}

The results for the third sub-construct of course organisation are presented in Table 10.

The results also showed high means and low standard deviations showing consistency of responses.

\section{Teaching modalities - 1}

The construct of teaching modalities had 14 questionnaire items, which needed to be split into sub-constructs using exploratory factor analysis. The results of the KaiserMeyer-Olkin Measure of Sampling Adequacy are high (0.916) and the Bartlett's Test of Sphericity is significant (chi-square $=1109.586, \mathrm{df}=91, p=0.000)$. This shows that the questionnaire items for teaching modalities can be split into sub-constructs as they are highly correlated. The results of reliability test demonstrate that the two subconstructs of teaching modalities are reliable (Cronbach's alpha $>0.700)$.

The results of the first teaching modalities sub-construct (factor 1) are presented in Table 11. 
TABLE 9: Effects of course organisation 2.

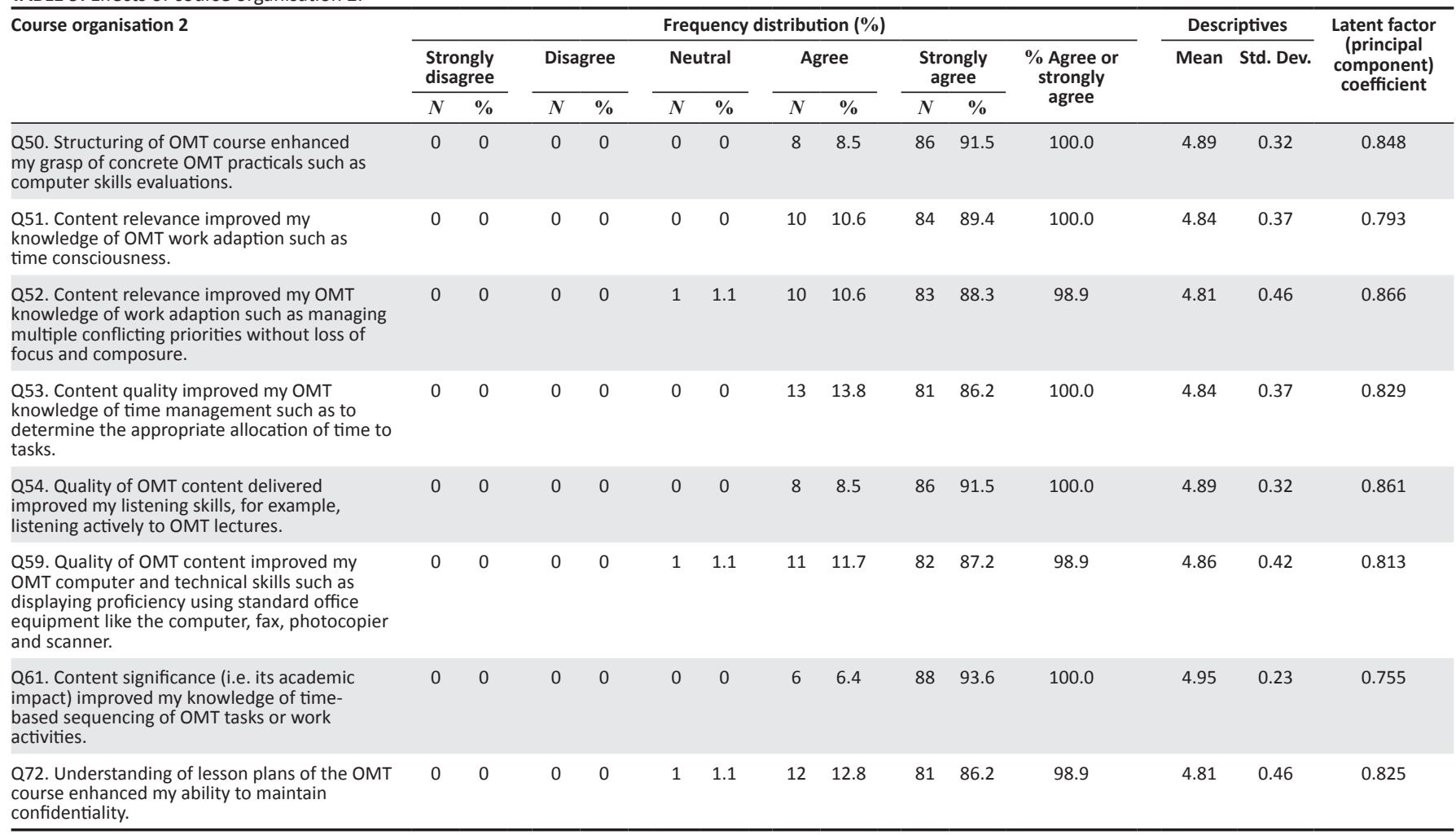

Cronbach's alpha $=0.929 ; \%$ of total variation accounted for by latent factor $=68.00$.

OMT, Office Management and Technology; Q, question; Std. Dev., standard deviation

TABLE 10: Effect of course organisation 3.

\begin{tabular}{|c|c|c|c|c|c|c|c|c|c|c|c|c|c|c|}
\hline \multirow[t]{3}{*}{ Course organisation 3} & \multicolumn{11}{|c|}{ Frequency distribution (\%) } & \multicolumn{2}{|c|}{ Descriptive } & \multirow{3}{*}{$\begin{array}{l}\text { Latent factor } \\
\text { (principal } \\
\text { component) } \\
\text { coefficient }\end{array}$} \\
\hline & \multicolumn{2}{|c|}{$\begin{array}{l}\text { Strongly } \\
\text { disagree }\end{array}$} & \multicolumn{2}{|c|}{ Disagree } & \multicolumn{2}{|c|}{ Neutral } & \multicolumn{2}{|c|}{ Agree } & \multicolumn{2}{|c|}{$\begin{array}{c}\text { Strongly } \\
\text { agree }\end{array}$} & \multirow{2}{*}{$\begin{array}{l}\text { \% Agree or } \\
\text { Strongly } \\
\text { Agree }\end{array}$} & \multirow[t]{2}{*}{ Mean } & \multirow[t]{2}{*}{ Std. Dev. } & \\
\hline & $N$ & $\%$ & $N$ & $\%$ & $N$ & $\%$ & $N$ & $\%$ & $N$ & $\%$ & & & & \\
\hline $\begin{array}{l}\text { Q55. Quality of OMT content improved my oral } \\
\text { skills (e.g. speaking confidently about OMT } \\
\text { concepts using clear and concise sentences). }\end{array}$ & 0 & 0 & 0 & 0 & 2 & 2.1 & 35 & 37.2 & 57 & 60.6 & 97.9 & 4.59 & 0.54 & 0.698 \\
\hline $\begin{array}{l}\text { Q56. Quality of content improved my time } \\
\text { management knowledge (such as determining } \\
\text { the appropriate allocation of time to OMT tasks). }\end{array}$ & 0 & 0 & 0 & 0 & 1 & 1.2 & 18 & 19.2 & 75 & 79.8 & 98.9 & 4.79 & 0.44 & 0.808 \\
\hline $\begin{array}{l}\text { Q62. Content significance improved my OMT } \\
\text { leadership skills such as: Team leadership. }\end{array}$ & 0 & 0 & 0 & 0 & 2 & 2.1 & 29 & 30.9 & 63 & 67.0 & 97.9 & 4.65 & 0.52 & 0.630 \\
\hline $\begin{array}{l}\text { Q70. Understanding of the lesson plans of the } \\
\text { OMT course broadened my ability to maintain } \\
\text { good working relationships with a diverse } \\
\text { workforce, customers and visitors. }\end{array}$ & 0 & 0 & 0 & 0 & 2 & 2.1 & 23 & 24.5 & 69 & 73.4 & 97.9 & 4.71 & 0.50 & 0.736 \\
\hline $\begin{array}{l}\text { Q71. Understanding of the lesson plans of } \\
\text { the OMT course enhanced my ability to lead } \\
\text { and provide instructions to clerical support } \\
\text { staff. }\end{array}$ & 0 & 0 & 0 & 0 & 1 & 1.2 & 12 & 12.8 & 81 & 86.2 & 98.9 & 4.85 & 0.39 & 0.822 \\
\hline
\end{tabular}

Cronbach's alpha $=0.780 ; \%$ of total variation accounted for by latent factor $=55.07$.

OMT, Office Management and Technology; Q, question; Std. Dev., standard deviation.

The first construct of teaching modalities has a very high internal consistency (Cronbach's alpha $=0.938$ ). All the mean scores on the effects of teaching modalities were high suggesting consistency of responses: improvement in OMT space management knowledge $(M=4.87, \mathrm{SD}=0.37)$ and task management knowledge $(M=4.87, \mathrm{SD}=0.37)$.

\section{Teaching modalities - 2}

The results of the second teaching modalities sub-construct (factor 2) are presented in Table 12.
The second construct of teaching modalities also had a very high internal consistency (Cronbach's alpha $=0.878$ ) and accounts for $73.47 \%$ of the information contained in the original questionnaire items before they are combined into one variable. The mean scores were high for all items of this sub-construct.

\section{Technology-assisted curricula delivery}

As with the aforementioned teaching-related components, the construct of technology-assisted curricula delivery also 
TABLE 11: Influence of teaching modalities (1).

\begin{tabular}{|c|c|c|c|c|c|c|c|c|c|c|c|c|c|c|}
\hline \multirow[t]{3}{*}{ Teaching modalities 1} & \multicolumn{11}{|c|}{ Frequency distribution (\%) } & \multicolumn{2}{|c|}{ Descriptives } & \multirow{3}{*}{$\begin{array}{l}\text { Latent factor } \\
\text { (principal } \\
\text { component) } \\
\text { coefficient }\end{array}$} \\
\hline & \multicolumn{2}{|c|}{$\begin{array}{l}\text { Strongly } \\
\text { disagree }\end{array}$} & \multicolumn{2}{|c|}{ Disagree } & \multicolumn{2}{|c|}{ Neutral } & \multicolumn{2}{|c|}{ Agree } & \multicolumn{2}{|c|}{$\begin{array}{c}\text { Strongly } \\
\text { agree }\end{array}$} & \multirow{2}{*}{$\begin{array}{l}\text { \% Agree or } \\
\text { strongly } \\
\text { agree }\end{array}$} & \multirow[t]{2}{*}{ Mean } & \multirow[t]{2}{*}{ Std. Dev. } & \\
\hline & $N$ & $\%$ & $N$ & $\%$ & $N$ & $\%$ & $N$ & $\%$ & $N$ & $\%$ & & & & \\
\hline $\begin{array}{l}\text { Q73. OMT lecturers' teaching enhanced my } \\
\text { adaptability knowledge such as managing } \\
\text { multiple conflicting priorities without loss of } \\
\text { composure. }\end{array}$ & 0 & 0 & 0 & 0 & 2 & 2.13 & 16 & 17.0 & 76 & 80.9 & 97.9 & 4.79 & 0.46 & 0.766 \\
\hline $\begin{array}{l}\text { Q75. OMT lecturers' teaching enhanced my } \\
\text { space management knowledge such as } \\
\text { appropriately handling all paperwork. }\end{array}$ & 0 & 0 & 0 & 0 & 1 & 1.06 & 13 & 13.8 & 80 & 85.1 & 98.9 & 4.84 & 0.40 & 0.832 \\
\hline $\begin{array}{l}\text { Q76. OMT lecturers' teaching enhanced my space } \\
\text { management knowledge such as maintaining } \\
\text { control over the physical OMT environment. }\end{array}$ & 0 & 0 & 0 & 0 & 2 & 2.13 & 9 & 9.6 & 83 & 88.3 & 97.9 & 4.86 & 0.40 & 0.906 \\
\hline $\begin{array}{l}\text { Q77. OMT lecturers' help broadened my task } \\
\text { management knowledge such as balancing } \\
\text { conflicting priorities in order to manage } \\
\text { workflow. }\end{array}$ & 0 & 0 & 0 & 0 & 1 & 1.06 & 10 & 10.6 & 83 & 88.3 & 98.9 & 4.87 & 0.37 & 0.847 \\
\hline $\begin{array}{l}\text { Q83. The practical orientation of the OMT } \\
\text { course (e.g. simulations and practicals) improved } \\
\text { my OMT space management knowledge such as } \\
\text { appropriately handling all paperwork. }\end{array}$ & 0 & 0 & 0 & 0 & 1 & 1.06 & 10 & 10.6 & 83 & 88.3 & 98.9 & 4.87 & 0.37 & 0.800 \\
\hline $\begin{array}{l}\text { Q84. The practical orientation of the OMT } \\
\text { course (e.g. simulations and practicals) improved } \\
\text { my OMT space management knowledge such as } \\
\text { maintaining control over the physical OMT } \\
\text { environment. }\end{array}$ & 0 & 0 & 0 & 0 & 2 & 2.13 & 10 & 10.6 & 82 & 87.2 & 97.9 & 4.85 & 0.41 & 0.885 \\
\hline $\begin{array}{l}\text { Q85. The practical orientation of the OMT } \\
\text { course (e.g. simulations and practicals) } \\
\text { broadened my OMT task management } \\
\text { knowledge such as balancing conflicting } \\
\text { priorities in order to manage the workflow. }\end{array}$ & 0 & 0 & 0 & 0 & 3 & 3.19 & 24 & 25.5 & 67 & 71.3 & 96.8 & 4.68 & 0.53 & 0.653 \\
\hline $\begin{array}{l}\text { Q86. The practical orientation of OMT course } \\
\text { (e.g. simulations and practicals) broadened my } \\
\text { OMT knowledge of organisational functions } \\
\text { and procedures of the office. }\end{array}$ & 0 & 0 & 0 & 0 & 3 & 3.19 & 12 & 12.8 & 79 & 84.0 & 96.8 & 4.81 & 0.47 & 0.775 \\
\hline
\end{tabular}

Cronbach's alpha $=0.938 ; \%$ of total variation accounted for by latent factor $=66.06$.

OMT, Office Management and Technology; Q, question; Std. Dev., standard deviation.

TABLE 12: Influence of teaching modalities (2).

\begin{tabular}{|c|c|c|c|c|c|c|c|c|c|c|c|c|c|c|}
\hline \multirow[t]{3}{*}{ Teaching modalities 2} & \multicolumn{11}{|c|}{ Frequency distribution (\%) } & \multicolumn{2}{|c|}{ Descriptives } & \multirow{3}{*}{$\begin{array}{l}\text { Latent factor } \\
\text { (principal } \\
\text { component) } \\
\text { coefficient }\end{array}$} \\
\hline & \multicolumn{2}{|c|}{$\begin{array}{l}\text { Strongly } \\
\text { disagree }\end{array}$} & \multicolumn{2}{|c|}{ Disagree } & \multicolumn{2}{|c|}{ Neutral } & \multicolumn{2}{|c|}{ Agree } & \multicolumn{2}{|c|}{$\begin{array}{c}\text { Strongly } \\
\text { agree }\end{array}$} & \multirow{2}{*}{$\begin{array}{l}\text { \% Agree or } \\
\text { strongly } \\
\text { agree }\end{array}$} & \multirow[t]{2}{*}{ Mean } & \multirow[t]{2}{*}{ Std. Dev. } & \\
\hline & $N$ & $\%$ & $N$ & $\%$ & $N$ & $\%$ & $N$ & $\%$ & $N$ & $\%$ & & & & \\
\hline $\begin{array}{l}\text { Q79. The practical orientation of the OMT } \\
\text { course (e.g. simulations and practicals) } \\
\text { improved my OMT knowledge such as } \\
\text { managing multi conflicting priorities without } \\
\text { loss of composure. }\end{array}$ & 0 & 0 & 0 & 0 & 2 & 2.1 & 18 & 19.2 & 74 & 78.7 & 97.9 & 4.77 & 0.47 & 0.743 \\
\hline $\begin{array}{l}\text { Q80. The practical orientation of the OMT } \\
\text { course (e.g. simulations and practicals) } \\
\text { improved my OMT knowledge such as } \\
\text { determining the appropriate allocation of } \\
\text { time on tasks. }\end{array}$ & 0 & 0 & 0 & 0 & 3 & 3.2 & 13 & 13.8 & 78 & 83.0 & 96.8 & 4.80 & 0.48 & 0.772 \\
\hline $\begin{array}{l}\text { Q81. OMT lecturers' helped to enhance my time } \\
\text { management knowledge such as determining the } \\
\text { appropriate allocation of time on tasks. }\end{array}$ & 0 & 0 & 0 & 0 & 2 & 2.1 & 14 & 14.9 & 78 & 83.0 & 97.9 & 4.81 & 0.45 & 0.705 \\
\hline
\end{tabular}

Cronbach's alpha $=0.878 ; \%$ of total variation accounted for by latent factor $=73.47$.

OMT, Office Management and Technology; Q, question; Std. Dev., standard deviation.

received a very high positive feedback from the students who participated in this study.

\section{Correlations between work integrated learning and student competencies}

Having presented the different competencies (i.e. space management knowledge, skills learning and abilities enhancement) independently in the previous sections, this section presents the results of correlations between these constructs (see Table 7). These constructs are reliable representatives of the questionnaire items that fall under them as indicated by the Cronbach's alpha values for each item, which indicated high reliability. The correlations show that all the WIL variables, in relation to overall influence of WIL on the enhancement of work place competencies (i.e. knowledge, skills and abilities), are significantly correlated with the variables that fall under the students' perspectives on the effect of the WIL programme on the broadening of OMT competencies.

Table 14 contains the correlations between the various constructs of WIL and students' perspectives on the effect of the WIL programme on the broadening of OMT knowledge, skills and abilities. 
TABLE 13: Influence of technology assisted curricula delivery.

\begin{tabular}{|c|c|c|c|c|c|c|c|c|c|c|c|c|c|c|}
\hline \multirow[t]{3}{*}{ Technology assisted curricula delivery } & \multicolumn{11}{|c|}{ Frequency distribution (\%) } & \multicolumn{2}{|c|}{ Descriptives } & \multirow{3}{*}{$\begin{array}{l}\text { Latent factor } \\
\text { (principal } \\
\text { component) } \\
\text { coefficient }\end{array}$} \\
\hline & \multicolumn{2}{|c|}{$\begin{array}{l}\text { Strongly } \\
\text { disagree }\end{array}$} & \multicolumn{2}{|c|}{ Disagree } & \multicolumn{2}{|c|}{ Neutral } & \multicolumn{2}{|c|}{ Agree } & \multicolumn{2}{|c|}{$\begin{array}{l}\text { Strongly } \\
\text { agree }\end{array}$} & \multirow[t]{2}{*}{$\begin{array}{l}\% \text { Agree or } \\
\text { strongly agree }\end{array}$} & \multirow[t]{2}{*}{ Mean } & \multirow[t]{2}{*}{ Std Dev } & \\
\hline & $N$ & $\%$ & $N$ & $\%$ & $N$ & $\%$ & $N$ & $\%$ & $N$ & $\%$ & & & & \\
\hline $\begin{array}{l}\text { Q88. The use of interactive technologies in the } \\
\text { OMT course improved my computational skills } \\
\text { like computer and technical skills such as } \\
\text { demonstrating advanced proficiency by quickly } \\
\text { adapting to new technology. }\end{array}$ & 0 & 0 & 0 & 0 & 2 & 2.1 & 8 & 8.5 & 84 & 89.4 & 97.9 & 4.87 & 0.39 & 0.835 \\
\hline $\begin{array}{l}\text { Q89. The use of interactive technologies in the } \\
\text { OMT course improved my computational skills } \\
\text { like computer and technical skills such as easily } \\
\text { acquiring new technical skills. }\end{array}$ & 0 & 0 & 0 & 0 & 2 & 2.1 & 5 & 5.3 & 87 & 92.6 & 97.9 & 4.90 & 0.36 & 0.870 \\
\hline $\begin{array}{l}\text { Q90. The use of instructional technology for } \\
\text { OMT demonstrations such as data projectors } \\
\text { enhanced my written skills such as producing } \\
\text { well thought-out texts. }\end{array}$ & 0 & 0 & 0 & 0 & 2 & 2.1 & 30 & 31.9 & 62 & 66.0 & 97.9 & 4.64 & 0.53 & 0.728 \\
\hline $\begin{array}{l}\text { Q91. The use of instructional technology for } \\
\text { OMT demonstrations such as data projectors } \\
\text { enhanced my written skills such as professional } \\
\text { correspondence free from grammatical and } \\
\text { spelling errors skills. }\end{array}$ & 0 & 0 & 0 & 0 & 2 & 2.1 & 10 & 10.6 & 82 & 87.3 & 97.9 & 4.85 & 0.41 & 0.694 \\
\hline
\end{tabular}

Cronbach's alpha $=0.829 ; \%$ of total variation accounted for by latent factor $=61.26$.

OMT, Office Management and Technology; Q, question; Std. Dev., standard deviation.

The four constructs of WIL are also highly correlated among themselves and have high effect sizes. Likewise, the seven constructs of students' perspectives on the effect of the WIL programme on the broadening OMT knowledge, skills and abilities are also highly and significantly correlated and have large effects sizes.

\section{Discussion}

\section{Influence of work integrated learning on the enhancement of knowledge of time management}

The dominant consensus $(100 \%)$ on the capacity of WIL to promote planning of tasks suggests that student immersion in work contexts contributed to their knowledge of professional work practices such as proper scheduling of routine work tasks and activities, which enhanced timeous execution of tasks. Therefore, the inculcation of knowledge on task planning transformed their work planning styles and reduced slack. Task planning is considered vital to increased production in work environments because regardless of the job role or responsibilities, every worker is a component of a group or team vital for the smooth functioning of an organisation (Kundasami, 2007, p. 45).

Time management knowledge concepts comprised knowledge of timeous execution of business functions, management of multiple conflicting priorities and proper allocation of time to various activities. The affirmative responses on student knowledge of timeous execution of business functions resonate with the claim that WIL ethos and practices are founded on the theory of experiential learning. The theory emphasises learners' transition from listening and visualising job-related concepts and constructs to the practical application of what they have been taught (Kolb \& Kolb, 2005, p. 45) and timeous execution of tasks is no exception. The finding on WIL's influence on students' timeous execution of business functions also corroborates Smith's (2012, p. 89) finding that participation in WIL impacted on student undertaking of authentic work activities such as knowing how business should operate and student interaction with a real-work context.

The affirmative responses on the potential of participation in WIL to improve the management of multiple conflicting priorities and proper allocation of time to tasks corroborate Clouder, Broughan, Jewell and Steventon's (2012, p. 78) claim that WIL is an educational approach that aligns academic and workplace practices for the mutual benefit of students and workplaces. Authentic work environments are considered to generate cognitive authenticity (Herrington \& Herrington, 2006) where students engage in personally meaningful and relevant learning (Smith, 2012; Stein, Andrews, \& Isaacs, 2001) through participation in real tasks. In the same vein, the capacity of WIL to influence students' time consciousness reinforces Martin, Hughes and Edwards' (2011, p. 66) finding that when students' OMT competencies are improved, their overall performance in any identified area and overall quality of their work in different learning contexts are also enhanced.

\section{Influence of work integrated learning on space management knowledge}

The almost universal response on the WIL's capacity to improve student knowledge of space management mirrors Cooper, Orrel and Bowden's (2010, p. 99) claim that WIL experiences provide students with the knowledge requisite for the management of space such as keeping the office clean all the times. The same finding also confirms the finding on the capacity of clinical practice (another form of WIL) to improve occupational therapy (OT) students' sound knowledge of 
TABLE 14: Correlations between Work Integrated Learning and students' perspectives.

\begin{tabular}{|c|c|c|c|c|c|c|c|c|c|c|c|c|}
\hline \multicolumn{2}{|c|}{ Pearson's correlations. } & \multirow{2}{*}{$\begin{array}{l}\text { Correlations } \\
\text { and } p \\
\text { values }\end{array}$} & \multicolumn{4}{|c|}{ Work Integrated Learning } & \multicolumn{6}{|c|}{$\begin{array}{l}\text { Students' perspectives on the effect of the WIL programme on the broadening } \\
\text { of office management and technology knowledge, skills and abilities }\end{array}$} \\
\hline & & & $\begin{array}{l}\text { Overall influence } \\
\text { of WIL on the } \\
\text { enhancement } \\
\text { of knowledge }\end{array}$ & $\begin{array}{c}\text { Space } \\
\text { management } \\
\text { knowledge }\end{array}$ & Skills & Abilities & $\begin{array}{l}\text { Lecture } \\
\text { content } \\
\text { selection }\end{array}$ & $\begin{array}{c}\text { Course } \\
\text { organisation } \\
1\end{array}$ & $\begin{array}{c}\text { Course } \\
\text { organisation } \\
\mathbf{2}\end{array}$ & $\begin{array}{c}\text { Course } \\
\text { organisation } \\
3\end{array}$ & $\begin{array}{c}\text { Teaching } \\
\text { modalities } \\
1\end{array}$ & $\begin{array}{c}\text { Teaching } \\
\text { modalities } \\
2\end{array}$ \\
\hline \multirow{9}{*}{$\begin{array}{l}\text { WIL related } \\
\text { competencies }\end{array}$} & \multirow{3}{*}{$\begin{array}{l}\text { Space } \\
\text { management } \\
\text { knowledge }\end{array}$} & Correlation & $0.711^{*}$ & - & - & - & - & - & - & - & - & - \\
\hline & & $p$-value & 0.000 & - & - & - & - & - & - & - & - & - \\
\hline & & $N$ & 94.000 & - & - & - & - & - & - & - & - & - \\
\hline & \multirow[t]{3}{*}{ Skills } & Correlation & $0.665^{*}$ & $0.747 *$ & - & - & - & - & - & - & - & - \\
\hline & & $p$-value & 0.000 & 0.000 & - & - & - & - & - & - & - & - \\
\hline & & $N$ & 94.000 & 94.000 & - & - & - & - & - & - & - & - \\
\hline & \multirow[t]{3}{*}{ Abilities } & Correlation & $0.746^{*}$ & $0.730 *$ & $0.804 *$ & - & - & - & - & - & - & - \\
\hline & & $p$-value & 0.000 & 0.000 & 0.000 & - & - & - & - & - & - & - \\
\hline & & $N$ & 94.000 & 94.000 & 94.000 & - & - & - & - & - & - & - \\
\hline \multirow{21}{*}{$\begin{array}{l}\text { Students' } \\
\text { perspectives } \\
\text { on the effect } \\
\text { of WIL } \\
\text { programme on } \\
\text { the broadening } \\
\text { office } \\
\text { management } \\
\text { and technology } \\
\text { knowledge, } \\
\text { skills and } \\
\text { abilities }\end{array}$} & \multirow{3}{*}{$\begin{array}{l}\text { Lecture } \\
\text { content } \\
\text { selection }\end{array}$} & Correlation & $0.562 *$ & $0.750 *$ & $0.749 *$ & $0.752 *$ & - & - & - & - & - & - \\
\hline & & $p$-value & 0.000 & 0.000 & 0.000 & 0.000 & - & - & - & - & - & - \\
\hline & & $N$ & 94.000 & 94.000 & 94.000 & 94.000 & - & - & - & - & - & - \\
\hline & \multirow{3}{*}{$\begin{array}{l}\text { Course } \\
\text { organisation } 1\end{array}$} & Correlation & $0.718^{*}$ & $0.781^{*}$ & $0.784 *$ & $0.800 *$ & $0.727^{*}$ & - & - & - & - & - \\
\hline & & $p$-value & 0.000 & 0.000 & 0.000 & 0.000 & 0.000 & - & - & - & - & - \\
\hline & & $N$ & 94.000 & 94.000 & 94.000 & 94.000 & 94.000 & - & - & - & - & - \\
\hline & \multirow[t]{3}{*}{$\begin{array}{l}\text { Course } \\
\text { organisation } 2\end{array}$} & Correlation & $0.767^{*}$ & $0.786^{*}$ & $0.749 *$ & $0.787^{*}$ & $0.759 *$ & $0.792^{*}$ & - & - & - & - \\
\hline & & $p$-value & 0.000 & 0.000 & 0.000 & 0.000 & 0.000 & 0.000 & - & - & - & - \\
\hline & & $N$ & 94.000 & 94.000 & 94.000 & 94.000 & 94.000 & 94.000 & - & - & - & - \\
\hline & \multirow[t]{3}{*}{$\begin{array}{l}\text { Course } \\
\text { organisation } 3\end{array}$} & Correlation & $0.697^{*}$ & $0.770 *$ & $0.710^{*}$ & $0.689 *$ & $0.642 *$ & $0.717^{*}$ & $0.737^{*}$ & - & - & - \\
\hline & & $p$-value & 0.000 & 0.000 & 0.000 & 0.000 & 0.000 & 0.000 & 0.000 & - & - & - \\
\hline & & $N$ & 94.000 & 94.000 & 94.000 & 94.000 & 94.000 & 94.000 & 94.000 & - & - & - \\
\hline & \multirow[t]{3}{*}{$\begin{array}{l}\text { Teaching } \\
\text { modalities } 1\end{array}$} & Correlation & $0.766^{*}$ & $0.839 *$ & $0.825^{*}$ & $0.850 *$ & $0.776 *$ & $0.866^{*}$ & $0.830 *$ & $0.735 *$ & - & - \\
\hline & & $p$-value & 0.000 & 0.000 & 0.000 & 0.000 & 0.000 & 0.000 & 0.000 & 0.000 & - & - \\
\hline & & $N$ & 94.000 & 94.000 & 94.000 & 94.000 & 94.000 & 94.000 & 94.000 & 94.000 & - & - \\
\hline & \multirow[t]{3}{*}{$\begin{array}{l}\text { Teaching } \\
\text { modalities } 2\end{array}$} & Correlation & $0.693 *$ & $0.724 *$ & $0.628^{*}$ & $0.635 *$ & $0.737^{*}$ & $0.693 *$ & $0.694 *$ & $0.638^{*}$ & $0.769 *$ & - \\
\hline & & $p$-value & 0.000 & 0.000 & 0.000 & 0.000 & 0.000 & 0.000 & 0.000 & 0.000 & 0.000 & - \\
\hline & & $N$ & 94.000 & 94.000 & 94.000 & 94.000 & 94.000 & 94.000 & 94.000 & 94.000 & 94.000 & - \\
\hline & \multirow{3}{*}{$\begin{array}{l}\text { Technology- } \\
\text { assisted } \\
\text { curricula } \\
\text { delivery }\end{array}$} & Correlation & $0.680^{*}$ & $0.747^{*}$ & $0.729 *$ & $0.830 *$ & $0.762 *$ & $0.761 *$ & $0.802^{*}$ & $0.740 *$ & $0.847^{*}$ & $0.667^{*}$ \\
\hline & & $p$-value & 0.000 & 0.000 & 0.000 & 0.000 & 0.000 & 0.000 & 0.000 & 0.000 & 0.000 & 0.000 \\
\hline & & $N$ & 94.000 & 94.000 & 94.000 & 94.000 & 94.000 & 94.000 & 94.000 & 94.000 & 94.000 & 94.000 \\
\hline
\end{tabular}

WIL, Work Integrated Learning.

*, Correlation is significant at the 0.01 level (2-tailed).

occupational health and safety principles, which allows them to assess the (cleanliness of) environment including clients' safety (Richmond, Richards, \& Britt, 2015).

The claim on the potential of WIL participation to enhance presentation skills could mean that activities prior to the presentation itself such as the planning for their presentation and conduct of rigorous research to ensure the delivery of a well-constructed message were also integral to delivering a good presentation. This finding resonates with Smith's (2014, p. 69) view on the need for business graduate employees to be equipped with an understanding of workplace oral communication skills. The fact that participation in WIL was conceived to improve the oratory abilities of students seems to cohere with Richmond et al.'s (2015) evidence on the potential of clinical practice (a form of WIL) to improve OT's communicative abilities such as self-introduction, building rapport and explaining the constitution of the OT discipline to clients. The same finding also mirrors Organ's (2017) finding on the impact of work placements on the transformation of English language learners' knowledge. His study reported that, upon completion of their placements, students had acquired fundamental work knowledge critical to their improved confidence and negotiation skills to work in other international educational contexts.

The popularity of the view that WIL participation improved students' computer skills resonates with the claim that students' participation in WIL enhanced their technology skills, which serves as an advantage in the contemporary 
business environment (Smith, 2012, p. 46). At the same time, the overwhelming consensus on the capacity of WIL participation to improve student adaptation to technology gels with the premise that, despite the variations in the terminologies used to describe WIL programmes and practices, they are all premised on the importance of enabling students to integrate theoretical knowledge gained through formal study into technical and practically oriented work contexts (Kundasami, 2007, p. 4).

By the same token, the popular view that work placements contributed to students' technical ability to operate machines (e.g. printers, scanners and binding machines) and other digital competencies such as word processing, faxing and photocopying documents points to the broad repertoire of technological skills that work placements foster and sustain. This finding also corresponds with Van Zyn's (2005, p. 163) observation that, while OMT focused traditionally on file handling and typing, the profession has since expanded with the advent of information and communication technologies to include managing computer documents and computer-based communication such as Skype (Van Zyn, 2005, p. 163).

The affirmative responses on WIL's influence on student leadership imply that, when fully developed and integrated into the work environment, such leadership can motivate fellow employees and transform the corporate world. The compelling evidence of leadership skills among students contradicts the popular employer discourse on graduate possession of 'discipline-specific' skills and their grappling with soft skills such as leadership and communication, in particular their application in work contexts (Business, Industry and Higher Education Collaboration Council report [BIHECC], 2007; Smith \& Worsfold, 2014). Perhaps, the academic levels at which students enrol for WIL and the varying context of application of such skills explain these differences. Nevertheless, the thriving of leadership skills gels well with Trede's (2012) claim that the great leaders' creation of a vivid and compelling vision of the future motivates fellow employees to want to achieve it, and more importantly, it is everyone's dream to work for a company that makes a difference in the world.

Students also gave very affirmative responses on the potential of WIL to increase their confidence levels in the work environment. According to Grabe (2010), the development of students' abilities during their participation in WIL depends on the capacity of employers to invest in the betterment of such abilities to increase their competence in the world of work. These findings resonate with Mcilveen et al.'s (2012, p. 26) claim that WIL tends to emphasise the concerns of employers and the workplace rather than those of students, and the balance is often tilted in favour of learning to work as opposed to learning to learn (Mcilveen et al., 2012, p. 26). Nevertheless, there was no hard evidence to support the view that students' academic competencies were compromised by their placements on the WIL programme.
The overwhelming responses on the potential of WIL to impact student inclination to follow work-based procedures cohere with the reasonable expectation for most business operations to rely on accurate procedures including complete and accurate workplace documents for communication, information management and record keeping to occur. As such, procedures may cohere with employers' expectations of students know how to write emails and letters, and complete documents and reports while avoiding mistakes (Van Zyn, 2005, p. 163).

\section{Correlations between work integrated learning and students' work-related competencies}

The results of correlation analysis between learning content and WIL demonstrate that lecture content selection is significantly and positively correlated with the overall influence of WIL on the enhancement of knowledge of time management, space management knowledge, skills and abilities. The high effect sizes of the correlations between WIL and lecture content selection suggest the strong integration of content selection with the workplace context activities. As Smith and Worsfold (2014) observe, a central trait of WIL approaches is the close integration of university study and professional or workplace practice, allowing integrative learning activities to engender the practical application of disciplinary knowledge learned at university to real-world work contexts.

The correlation between the first construct of course organisation (course organisation 1) and WIL demonstrates that course organisation is significantly and positively correlated with the overall influence of WIL on the enhancement of knowledge of time management, space management knowledge, skills and abilities. The correlations had high effect size demonstrating that there is a strong relationship between WIL and course organisation 1. When WIL is wholly embedded into university programmes, these programmes tend to create more than just work experience and improve university-occupational links (Atkinson, 2016).

The results of this study also revealed that the second construct of course organisation (course organisation 2) is significantly and positively correlated with the overall influence of WIL on the enhancement of knowledge of time management, space management knowledge, skills and abilities, and the correlations had high effect sizes. Although the relationships demonstrated high level of student proficiency and high level of significance, there is a need to gauge student levels of competencies from the employers, and educators' perspectives to determine students' work readiness, levels of intellectual rigor, critical analysis, and application and cultural awareness (Whelan, 2017). The study noted marked differences between employers' and and educators' perceptions on students' skills acquired from their participation in WIL - while teaching staff perceived students' skills as 'adequate', the students and host supervisors perceived students' skills to be approaching the 'proficient' level. 
The results of the study also demonstrated that the first construct of teaching modalities (teaching modalities 1) is significantly and positively correlated with the overall influence of WIL on the enhancement of time management knowledge, space management knowledge, skills and abilities. The correlations are of high effect size; hence, there is a strong relationship between WIL and teaching modalities 1 . This could imply that good pedagogical practices trigger improved knowledge production in the work environment during and after the WIL programme. Henderson and Trede (2017) highlight that some tangible benefits of WIL include development of good practices based on students' knowledge and research evidence, such as the opportunity to glean their fresh ideas, knowledge, skills and approaches. More so, after students' workplace experience, industry staff can also reflect upon these new ideas and approaches introduced and consider how these may be useful to the industry (Henderson \& Trede, 2017).

\section{Recommendations}

The strong correlation between course organisation (course organisation 1) and overall influence of WIL on the enhancement of knowledge of time management, space management knowledge, skills and abilities implies that educators and employers need to place more emphasis not just on their delivery methods but also on the selection and organisation of course materials, which is critical to such delivery.

The strong correlation between teaching modalities and the overall influence of WIL on the enhancement of knowledge, space management knowledge, skills and abilities demonstrates the central role that pedagogical delivery plays in the enhancement of student competencies. As such, educators should put equal attention on the delivery mechanisms and modes to ensure that the choice of the delivery mode coheres with the discipline students are enrolled in, their learning styles and their academic levels and the rationale of the WIL programmes.

The results also showed that technology-assisted curricula delivery is significantly and positively correlated with the overall influence of WIL on the enhancement of various competencies. Although this may demonstrate the high technology-dependent nature of OMT activities and tasks, it also demonstrates the centrality of technology in catalysing the effective implementation of WIL. Therefore, rather than adopting technology as an appendage (an 'add on') of WIL conceptualisation and implementation processes, educators should make technology more integral to their administration of WIL programmes by incorporating technology at WIL conceptualisation, integrating it at WIL content selection, organisation and delivery.

\section{Implications for future research and conclusion}

Although the current research focused on students' perspectives in resource-constrained contexts, future studies should incorporate educators and employers' perspectives on the capacity of WIL to broaden student competences and compare them with student perspectives. This will provide a more integrated view of such perspectives of WIL that will be beneficial to universities' student-supported career planning, students' academic and professional growth and employers' aspirations about student competencies.

Although this focus foregrounded third year students who already had a detailed experience of university education, it may not be clear whether their positive affirmation of WIL was a consequence of their extended university experience or an outcome of their genuine and authentic interaction with the work environment. As such, exposing junior students (e.g. first or second year students) to WIL, and then comparing their experiences to those of third years, will provide a more comprehensive picture of the motivations for the overly positive affirmations of WIL. Although the OMT competences were the main focus of the research, future studies should investigate the impact of WIL on the improvement of broader competencies such as general management and strategic competencies.

The study criticised employability-centric and employercentric perspectives adopted by most of WIL studies, which tend to negate the perspectives of the students who actually participate in such programmes. The study took a student perspective by concentrating on the extent to which student participation in WIL positively influenced a broad range of student competencies. The findings demonstrated that a variety of knowledge, skills and abilities were positively influenced by student participation in WIL programmes.

\section{Acknowledgements}

The author thanks Nomfundo Gladys Khoza for the collection of data that contributed to the write up of this article.

\section{Competing interests}

The author declares that he has no financial or personal relationships that may have inappropriately influenced him in writing this article.

\section{References}

American Public Human Service Association. (2012). A guidebook for building organisational performance capacity: A training system example. Washington, DC: American Public Human Service Association.

Atkinson, G. (2016). Work-based learning and work-integrated learning: Fostering engagement with employer. Adelaide: National Centre for Vocational Education Research.

Bagozzi, R.P. (2011). Measure and meaning in information systems and organisational research: Methodological and philosophical foundations. MIS Quarterly, 35(2), 261-292. https://doi.org/10.2307/23044044

Barrows, C., \& Johan, N. (2008). Hospitality management education. In B. Brotherton \& R. Wood (Eds.), The Sage handbook of hospitality management (pp. 146-162). London, UK: Sage.

Beckett, D. (2004). Embodied competence and generic skills: The emergence of inferential understanding. Educational Philosophy and Theory, 36(5), 497-508. https://doi.org/10.1111/j.1469-5812.2004.086_1.x

Biasini, R., Bohm, A., \& Rabadán-Gómez, M. (2016). Independent work placements as a gateway to the world of work. In E. Corradini, K. Borthwick, \& A. Gallagher-Brett (Eds.), Employability for languages: A handbook (pp. 39-42). Dublin: ResearchPublishing. 
Billet, S. (2011). Curriculum and pedagogical bases for effectively integrating practicebased experiences. Strawberry Hills, NSW: Australian Learning and Teaching based experiences
Council (ALTC).

Brimble, M., \& Freudenberg, B. (2010, April 28). Will WIL'ing work? B-HERT News, pp. 2-4.

Brookfield, S.D. (2012). Teaching for critical thinking: Tool and techniques to help students question their assumptions. San Francisco, CA: Jossey-Bass.

Burgess, A.W., Roberts, C., Black, K.I., \& Mellis, C. (2013). Senior medical student perceived ability and experience in giving peer feedback in formative long case examinations. BMCMedical Education, 13(1), 79-84. https://doi.org/10.1186/1472 6920-13-79

Business, Industry and Higher Education Collaboration Council (BIHECC). (2007). Graduate employability skills. Canberra: BIHECC.

Clouder, L., Broughan, C., Jewell, S., \& Steventon, G. (2012). Improving student engagement and development through assessment (1st edn.) London: Routledge.

Cooper, L., Orrel, J., \& Bowden, M. (2010). Work integrated learning: A guide to effective practice. London: Routledge.

Crawford, I., \& Wang, Z. (2015). The effect of work placements on the academic performance of Chinese students in UK higher education. Teaching in Higher Education, 20(6), 569-586. https://doi.org/10.1080/13562517.2015.1045860

Dressler, S., \& Keeling, A. (2011). Benefits of cooperative and work-integrated education for students. In R. Coll \& K. E. Zegwaard (Eds.), International handbook for cooperative and work-integrated education (pp. 261-275). Lowell, MA: World Association for Co-operative Education.

Ferreira, D. (2011). Terminology measurement in South Africa. A review of three working methods. In T. Kruit, E. Ruijsendaal, W. Martin, \& H. van der Vliet (Eds.), Terminology for Europeans (and beyond). Proceedings of the International Symposium of Terminology Service Centres (pp. 47-54). Gent: Association for Dutch Terminology and Dutch Language Union, Academia Press.

Grabe, W. (2010). Fluency in reading-thirty-five years later. Reading in a Foreign Language, 22(1), 71-83.

Graham, L., \& De Lannoy, A. (2016). South Africa's youth unemployment rates are now considered to be chronic. The latest figures show that about $48 \%$ of South Africans between 15 and 34 were unemployed in the third quarter of 2016 Retrieved between 15 and 34 were unemployed in the third quarter of 2016 Retrieved
December 07, 2017, from http://www.sowetanlive.co.za/news/2017/02/14/ December 07, 2017, from http://www.sowetanlive.co.za/news/2017/0
what-south-africa-can-do-about-youth-unemployment-in-the-short-run

Henderson, A., Alexander, H., Haywood, A., Stapleton, P., Cooke, M., Patterson, E., .. Creedy, D. (2010). Promoting and providing expert guidance in work-intensive Creedy, D. (2010). Promoting and providing expert guidance in work-intensive
clinical settings. Vocations and Learning, 13(2), 141-150. https://doi.org/10.1007/ clinical settings. Vocatio

Henderson, A., \& Trede, F. (2017). Strengthening attainment of student learning outcomes during work-integrated learning: A collaborative governance framework across academia, industry and students. Asia-Pacific Journal of Cooperative Education, 18(1), 73-80.

Herrington, A., \& Herrington, J. (2006). Authentic learning environments in higher education. Hershey, PA: Information Science Publishing.

Jackson, D. (2015). Employability skill development in work-integrated learning Barriers and best practice. Studies in Higher Education, 40(2), 350-367. https:// doi.org/10.1080/03075079.2013.842221

Jackson, D., \& Wilton, N. (2016). Developing career management competencies among undergraduates and the role of work-integrated learning. Teaching in Higher Education, 21(3), 266-286. https://doi.org/10.1080/13562517.2015.1136281

Jones, C.M., Green, J.P., \& Higson, H.E. (2017). Do work placements improve final year academic performance or do high-calibre students choose to do work placements? Studies in Higher Education, 42(6), 976-992. https://doi.org/10.108 0/03075079.2015.1073249

Khuong, C.T. (2016). Work-integrated learning process in tourism training programs in Vietnam: Voices of education and industry. Asia-Pacific Journal of Cooperative Vietnam: Voices of education
Education, 17(2), 149-161.

Kolb, A., \& Kolb, D. (2005). Learning styles and learning space: Enhancing experiential learning in higher education. Academy of Management Learning \& Education 4(2), 193-212. https://doi.org/10.5465/AMLE.2005.17268566

Kolb, D. (1984). Experiential learning: Experience as the source of learning and development. Upper Saddle River, NJ: Prentice Hall.

Kundasami, V. (2007). The assessment of work-integrated learning at a University of Technology. Pretoria: University of Pretoria.

Lehohla, P. (2017). Statistician-general speech at the release of Statistics SA's Quarterly Labour Force Survey. Statistics South Africa, Pretoria.

Little, B., \& Harvey, L. (2006). Learning through work placements and beyond. York: Centre for Research and Evaluation and Centre for Higher Education Research and Information.

Maher, J., Pelly, F., Swanepoel, E., Sutakowsky, L., \& Hughes, R. (2015). The contribution of clinical placement to nutrition and dietetics competency development: A student-centred approach. Nutrition and Dietetics, 72, 156-162. https://doi.org/ 10.1111/1747-0080.12163
Martin, S., Hughes, L., \& Edwards, E. (2011). Writing in the business profession. Cape Town: Dannels.

Mcilveen, K., Mcnamara, J., Kift, K., Butler, S.D., Field, K., Brown, W., \& Gamble, D. (2012). Training management in South Africa. Cape Town: Oxford University Press.

McRae, N., \& Johnston, N. (2016). The development of a proposed global workintegrated learning framework. Asia-Pacific Journal of Cooperative Education, 17(4), 337-348.

Menon, S. (2017). SA's unemployment rate hits a 13-year high. Retrieved from https:// www.timeslive.co.za/news/south-africa/2017-06-01-sas-unemployment-ratehits-a-13-year-high/

Milne, L., \& Caldicott, J. (2016). Exploring differences in industry supervisors' ratings of student performance on WIL placements and the relative importance of skills: Does remuneration matter? Asia-Pacific. Journal of Cooperative Education, 17(2) 175-186.

Organ, A. (2017). Languages in the workplace: Embedding employability in the foreign language undergraduate curriculum. In C. Álvarez-Mayo, A. Gallagher-Brett, \& F. Michel (Eds.), Innovative language teaching and learning at university: Enhancing employability (pp. 37-45). Research-publishing.net. Retrieved November 05, 2017, from https://doi.org/10.14705/rpnet.2017

Peters, J., Sattler, P., \& Kelland, J. (2014). Work-integrated learning in Ontario's postsecondary sector: The pathways of recent college and university graduates. Toronto, Canada: Higher Education Quality Council of Ontario (HEQCO).

Pretorius, J. (2012). A language act for South Africa? Principles, viability and practice. Bloemfontein: University of Free State.

Puncreobutr, V., Malee, \& Somjate. (2016). Linking work integrated learning and competency of graduates pursuing graduate diploma in teaching profession. competency of graduates pursuing graduate dip
Journal of Education and Practice, $7(10), 121-127$.

Richmond, K., Richards, K., \& Britt, K. (2015). The impact of an authentic, simulated learning activity on student preparedness for work-integrated learning. AsiaPacific Journal of Cooperative Education, 16(4), 343-354.

Rubinstein, J.S., Meyer, D.E., \& Evans, J.E. (2001). Executive control of cognitive processes in task switching. Journal of Experimental Psychology, 27(4), 763-797. https://doi.org/10.1037/0096-1523.27.4.763

Salm, T.L., Johner, R., \& Luhanga, F. (2016). Determining student competency in field placements: An emerging theoretical model. The Canadian Journal for the Scholarship of Teaching and Learning, 7(1), Article 5. Retrieved November 07 2017, from http://ir.lib.uwo.ca/cjsotl_rcacea/vol7/iss1/5

Sattler, P., Wiggers, R., \& Arnold, C. (2011). Combining workplace training with postsecondary education: The spectrum of Work- Integrated Learning (WIL) opportunities from apprenticeship to experiential learning. Canadian Apprenticeship Journal, 5. Retrieved November 13, 2017, from http://journals.sfu. $\mathrm{ca} / \mathrm{caj} /$ index.php/caj-jca/article/view/74/131

Simpson, P., Thyer, L., Van Nugteren, B., Mitchell, G., \& Werner, S. (2016). Reflections and experiences of student paramedics undertaking international workintegrated learning placements. Asia-Pacific Journal of Cooperative Education 17(2), 187-196.

Smith, C., \& Worsfold, K. (2014). WIL curriculum design and student learning: A structural model of their effects on student satisfaction. Studies in Higher Education, 39(6), 1070-1084. https://doi.org/10.1080/03075079.2013.777407

Smith, C.D. (2012). Evaluating the quality of work-integrated learning curricula: A comprehensive framework. Higher Education Research and Development, 31(2), 247-262. https://doi.org/10.1080/07294360.2011.558072

Statistics South Africa. (2017). Quarterly labour force survey quarter 1: 2017. Statistical release P0211. Pretoria, South Africa: Statistics South Africa.

Stein, S., Andrews, T., \& Isaacs, G. (2001). Incorporating authentic learning experiences within a business management course, Australian Association for Research in Education. Queensland: The University
University of Queensland, Queensland.

Tai, J., Molloy, E., Haines, T., \& Canny, B. (2016). Same-level peer-assisted learning in medical clinical placements: A narrative systematic review. Medical Education, 50 469-484. https://doi.org/10.1111/medu.12898

Trede, F., 2012. Role of work integrated learning in developing professionalism and professional identity. Asia-Pacific Journal of Cooperative Education, 13(3), 159-167.

Van Zyn, D. (2005). Marketing research. Cape Town: Johnson.

Whelan, M. (2017). Road testing graduate attributes and course learning outcomes of an environmental science degree via a work integrated learning placement. AsiaPacific Journal of Cooperative Education, 18(1), 1-13.

Wilton, N. (2012). The impact of work placements on skills development and career outcomes for business and management graduates. Studies in Higher Education, 37(5), 603-620. https://doi.org/10.1080/03075079.2010.532548

Yorke, M. (2011). Work-engaged learning: Towards a paradigm shift in assessment. Quality in Higher Education, 17(1), 117-130. https://doi.org/10.1080/13538322.2 011.554316 